Georgia State University

ScholarWorks @ Georgia State University

Early Childhood and Elementary Education

Faculty Publications

Early Childhood and Elementary Education

Department

3-2019

\title{
The Nicaraguan diaspora in Costa Rica: Schools and the disruption of transnational social fields
}

Ana T. Solano-Campos

Georgia State University, asolanocampos@gsu.edu

Follow this and additional works at: https://scholarworks.gsu.edu/ece_facpub

Part of the Pre-Elementary, Early Childhood, Kindergarten Teacher Education Commons

\section{Recommended Citation}

Solano-Campos, Ana T., "The Nicaraguan diaspora in Costa Rica: Schools and the disruption of transnational social fields" (2019). Early Childhood and Elementary Education Faculty Publications. 13. https://scholarworks.gsu.edu/ece_facpub/13

This Article is brought to you for free and open access by the Early Childhood and Elementary Education Department at ScholarWorks @ Georgia State University. It has been accepted for inclusion in Early Childhood and Elementary Education Faculty Publications by an authorized administrator of ScholarWorks @ Georgia State University. For more information, please contact scholarworks@gsu.edu. 


\title{
Author Accepted Manuscript
}

Solano-Campos, A. (2019b). The Nicaraguan diaspora in Costa Rica: Schools and the disruption of transnational social fields. Anthropology and Education Quarterly, 50(1), 48-65.

The Nicaraguan Diaspora in Costa Rica:

\section{Schools and the Disruption of Transnational Social Fields}

\author{
Ana Solano-Campos
}

\begin{abstract}
This ethnographic case study explores Nicaragua-Costa Rica cross-border dynamics, one of the most important South-South migration flows in the Central American region. I identify practices that prevent Nicaraguan children in a Costa Rica classroom from consolidating transnational identities and networks during the school day. Specifically, I examine three types of disruptions - historical, social, and linguistic - as well as various ways in which students and teachers contest those disruptions.

Keywords: transnational social fields, Nicaraguan diaspora, South-South migration, Costa Rican schools
\end{abstract}




\title{
Author Accepted Manuscript
}

Solano-Campos, A. (2019b). The Nicaraguan diaspora in Costa Rica: Schools and the disruption of transnational social fields. Anthropology and Education Quarterly, 50(1), 48-65.

The Nicaraguan Diaspora in Costa Rica:

\section{Schools and the Disruption of Transnational Social Fields}

\author{
Ana Solano-Campos
}

In a binational Costa Rican classroom, the transnational identities and ties of Nicaraguan children, typically nurtured by their communities, are constantly disrupted in their everyday lives at school. Three types of disruption - historical, social, and linguistic — contributed to students' systematic exclusion from both the Costa Rican and Nicaraguan national imaginaries. To date, the expanding body of research examining the education of Nicaraguan children and youth in Costa Rican schools has provided varying types of evidence of the persisting exclusion and inequity that Nicaraguan students encounter in academic spaces. However, the relationship between nation-centered inequitable educational practices and students' transnational ways of being and belonging have rarely entered these conversations.

In this article, I examine how the case of Nicaragua-Costa Rica cross-border dynamics is both a typical and singular example of South-South migration. Even when Nicaraguan immigrants do not immediately experience a language barrier upon entering the neighboring nation of Costa Rica - as people in both countries speak Spanish — a Nicaraguan accent quickly 
becomes a marker of otherness that unravels processes of linguistic differentiation by which immigrants are discriminated against based on pervasive raciolinguistic ideologies (Flores \& Rosa, 2015). As such, the treatment of Nicaraguan children and second-generation children of Nicaraguan descent in Costa Rican schools unfortunately follows patterns of discrimination and violence, symbolic or otherwise, reported in the literature on South-South migration (Bartlett, 2012; Bartlett \& Ghaffar-Kucher, 2013; Chrush \& Tawodzera, 2013; Ferris \& Winthrop, 2010; Dryden-Peterson, 2009).

After contextualizing Nicaragua-Costa Rica cross-border dynamics, I provide an overview of the educational conditions of immigrant children in Costa Rica. Then, I elaborate on the conceptual framework underpinning this study, followed by a description of the fieldwork and participants. Finally, I present and illustrate the findings, discussing afterwards implications and avenues for research and praxis.

\section{South-South Migration and the Nicaraguan Diaspora in Costa Rica}

Nicaragua-Costa Rica cross-border dynamics are one of the most important South-South migration flows in the Central American region (Arias, 2014; International Organization for Migration, 2013). Migrants from Nicaragua are dispersed across the world, particularly in the United States (mainly Miami) and Costa Rica, the majority having left the country in the second half of the twentieth century. Most of this dispersal happened in the 1970s and 1980s, when Nicaragua experienced a time of upheaval and violence under the Somoza dictatorship and subsequently during the Nicaraguan revolution.

However, Orozco (2005) explains that until recently, Nicaraguan migrant communities were rarely imagined — and rarely imagined themselves—as part of a Nicaraguan diaspora mainly because of political polarization between Sandinistas and Somozistas (p. 5). New positive 
attitudes in Nicaraguans' perception of emigrants have lifted the veil surrounding the construction of Nicaraguan diasporic spaces (de la Garza \& Orozco, 2000). Transnational flows to Costa Rica have been particularly important in this shift, with the emergence of discourses that position Nicaraguan migration to Costa Rica as the pursuit of "the Costa Rican dream" and that reflect meritocratic narratives usually associated with South-North migration in countries like the United States.

Nicaragua-Costa Rica migration flows have been framed by disputes about the Costa Rican-Nicaraguan border that date back to colonial years (Sandoval García, 2004). Postindependence, official records show seasonal migration of Nicaraguans to Costa Rica mainly "to assist in the banana industry, and later in coffee and other export-commodity industries" (Mahler \& Ugrina, 2006). Subsequent waves of migration have been spurred by "push and pull” economic, political, and social dynamics (Locke \& Ovando, 2012a, p.136), among them natural disasters and civil unrest exacerbated by foreign intervention. The immigration of Nicaraguans to Costa Rica is also framed by a narrative of exceptionality in which Costa Rica is exalted as an egalitarian, literate, white country (Sandoval Garcia, 2004), and in which Nicaraguans are constructed as the opposite: violent, illiterate, and non-white; characteristics that make them "undesirable" (Alvarenga, 2011, p.18).

The othering of Nicaraguan immigrants takes place and is perpetuated through processes of racialization and accentuation of difference (Sandoval-Garcia, 2004). Immigration to Costa Rica has been informed by colonial understandings that position European features as desirable. According to Alvarenga (2011), in the mid-20th century European immigration to Costa Rica was encouraged, but the immigration of African and Chinese workers, among others, was barely tolerated. There was a predominance of "racialized representations that consider[ed] Costa Rica 
to be a nation inhabited by 'white' people” (Sandoval-García, 2004, p. xv), even when most

Costa Ricans can be best described as mestizos. Thus, Nicaraguan immigrants in Costa Rica are ascribed racial identities and positioned within racial hierarchies in order to facilitate discourses about the whiteness and exceptionality of Costa Ricans. In being racialized, Nicaraguan immigrants are constructed as embodying alleged markers of foreignness that they cannot change.

\section{Nationalism, Immigration, and Education}

Costa Rica has a long history of involvement with human rights and peace education. The country adheres to several national and international norms to protect the rights of immigrant students, among them the Costa Rican Code of Childhood and Adolescence, the Universal Declaration of Human Rights, and the Convention on the Rights of the Child. The Ministerio de Educación [Ministry of Education] (2013) specifically outlines that "all children and youth who reside in Costa Rica have the right and responsibility to attend school, regardless of their nationality, country of origin, or ethnic group" (p. 29) and that no student in Costa Rica should be denied enrollment in school because of a lack of immigration documents.

In spite of this, the rhetoric of Nicaraguan undesirability is pervasive in formal education settings. Although Nicaragua and Costa Rica are commonly described in the media and popular culture as naciones hermanas [sister nations] and their contentious relationship as a "sibling rivalry," these metaphors are not the only discourses being disseminated about Nicaraguans. The media and popular culture also play an important role in circulating narratives about the deficit of Nicaraguans within and outside schools (Sandoval Garcia, 2004). In educational settings, such narratives are also circulated through the attitudes and curriculum that immigrant students encounter at school. In her study of testimonios [first-person narratives] from both Nicaraguan 
and Costa Rican children and youth in La Carpio - the largest binational community in the country, located in the province of San José, Costa Rica's capital-Paniagua Arguedas (2007) found that Nicaraguan children are consistently othered in Costa Rican schools. This othering takes place through what she identified as three symbolic borders: the exclusion of immigrant children from educational institutions, the creation and perpetuation of hostile spaces and discriminatory attitudes in classrooms, and the implementation of Costa Rican-centric content and curriculum.

Subsequent research has highlighted the xenophobia-based assumptions that drive the marginalization of Nicaraguan children in academic spaces. For one, discrimination against Nicaraguan students seems to increase when children display perceived markers of a Nicaraguan identity such as a dark skin color and a Nicaraguan accent (Araya Madrigal \& Hernandez Carballo, 2011; Purcell-Gates, 2008). When these markers of identity are present, students often experience "pedagogies of silence” (Ruiz Guevara, 2009, p. 25). Even if students successfully overcome the barriers they encounter in Costa Rican schools, longitudinal research by Locke and Ovando (2012b) shows that "[e]ventually Nicaraguans hit a glass ceiling that limit[s] their upward mobility and force[s] them to find alternative paths to achieve their goals," in many cases returning to Nicaragua to pursue higher education.

The case of Nicaraguan students in Costa Rican schools is representative of scholarly concerns about the types of (trans)national affiliations that immigrant children are "permitted" to build and display in public spaces in receiving countries (Dyrness \& Sepúlveda, 2015; JaffeWalter, 2016; Koh, 2010; Moinian, 2009; Ríos-Rojas, 2014). Schools often construct immigrant students as subjects to be governed (Foucault, 1991), conditioning their belonging and disciplining their aspirations (Jaffe-Walter, 2016) in ways that greatly hinder their cultural 
citizenship rights (Ong, 1999; Rosaldo, 1997). In spite of the pervasive nationalizing and marginalizing function of schools, immigrant and refugee children bring with them a wealth of resources, networks, relationships, and "transnational educational capital” (Chrostowsky \& Long, 2013) to receiving countries. Not only that, immigrant students are active agents in resisting nation-centered discourses, often mobilizing sociocultural and historical narratives and counterstories to advocate for spaces that recognize their unique and hybrid (trans)national and diasporic identifications (Jaffe-Walter, 2016; Moinian, 2009; Koh, 2010).

\section{A Critical Transnational Perspective}

In this study, I aim to capture students' "experiences of living simultaneously within and beyond the boundaries of a nation-state" (Levitt \& Schiller, 2004, p. 1006). Grounded in the interdisciplinary field of cross-border studies, I situated this research at the intersection of anthropological and sociological understandings of (in)migration. Drawing from Bourdieu's $(1991,1993)$ foundational work on fields and symbolic power, I approached this inquiry with the understanding that schools are fields in which various forms of capital are (re)produced and legitimized in inequitable ways. I further positioned schools in contexts of high migration as existing within transnational social fields (Levitt \& Schiller, 2004), that is, arenas in which overlapping social networks that are structured by unequal power dynamics expand across nations (p. 1009). In addition, I intentionally centered students' transnationality (Kivisto \& Faist, 2010, p. 310), which refers not only to physical or geographical mobility and network building across time and space, but also to processes of identity expansion and transcendence that happen regardless of place or territory (Castles, 2004).

In contrast to the isolationist narrative of Costa Rican exceptionality, the countries of Central America have been part of a transnational milieu of sorts since pre-colonial times, 
sharing various temporalidades — instances where a common Mesoamerican and colonial history is expressed in quite distinctive ways (Ansaldi, 2001; Hopenhayn, 2002) - that have carried on until present day. Thus, I situated the transnational identity and relationship building and maintenance of Nicaraguan immigrants in Costa Rican schools within historical, racial, and linguistic imaginaries that have permeated the Central American region and which bound Nicaragua and Costa Rica together. In order to better understand these dynamics, I used Glick Schiller's (2005) critical orientation to transnationalism, which involves looking at the mechanisms that produce and contest inequity across state boundaries.

The nationalizing function of schools consistently attempts to decenter students' transnational identifications and networks in public educational spaces by deploying various tools to delegitimize (or erase) the bonds between Nicaragua and Costa Rica. In the case of Nicaraguan children in Costa Rica, although the educational inequities and experiences of discrimination that they encounter in schools are well documented, we know little about how transnational social fields interact with or inform the educational spaces that students and teachers inhabit. I expand on this area of research by asking: How do Nicaraguan children experience transnational social fields at school? What are the mechanisms by which schools support or hinder students' transnational identities and relationships? How do teachers and students understand and use those mechanisms?

\section{Positionality}

I am a U.S.-based sociolinguist and language educator. I was born and raised in a middleclass family in Costa Rica and identify as racially white. I have been a student, teacher, and researcher in both countries and have worked with emergent bilingual immigrant/refugee children and their teachers across both settings. My engagement with the fieldwork context goes 
back to my formative years. Having been educated in the Costa Rican public school system, I am intimately familiar with the historical and sociocultural context of education in the country. As I grew up and went to school in the Central Valley, my Spanish accent is typically characterized as the norm. My familiarity with formal education in Costa Rica and my proficiency in standard Costa Rican Spanish were forms of social capital that enabled my access to the field site and endowed me with crucial foundational (insider) knowledge and networks. In addition, as an English-speaking researcher affiliated with an institution of higher education in the United States, I re-entered the Costa Rican context from a position of heightened academic and social privilege.

Consequently, my fieldwork was informed by my own transnationality and by the tensions between the inherent alterity and unexpected bestrangement, or defamiliarization, of going back to my country of origin to conduct research. As both, a Costa Rican and a firstgeneration Latina immigrant in the United States, I operated within a third space (Bhabba, 1994) in which various flexible identities intersected at different times to mediate my interactions with participants and my interpretation of the information they shared with me. For example, whereas the Costa Rican children and teachers identified with me as a fellow Tica [short for Costa Rican], the Nicaraguan children related to my experience as an "other" in the United States.

\section{Fieldwork}

I conducted fieldwork in Costa Rica's Gran Area Metropolitana [Great Metropolitan Area], which is home to the largest number of Nicaraguan immigrants in the country. As an urban area at the core of (im)migrant dynamics and cultural production, the social and educational landscape in the province of Heredia, my home town, lent itself to the purpose of this study. Heredia is located in Costa Rica's Central Valley, north of the province of San José and 
directly bordering Nicaragua. My entry point was Escuela Montaña Verde (EMV, pseudonym), a K-6 school located in the district of San Francisco. Montaña Verde enrolled a significant number of children from Nicaraguan and binational backgrounds, most of them residing in La Quebrada (pseudonym), a grouping of various communities located near the school and often described as of the largest precarios [shantytowns] in the nation. In selecting Montaña Verde, I was intentional about choosing a site where transnational spaces and relationships predominated.

I gathered the data for this research as part of a comparative study to examine SouthNorth and South-South processes of migrant incorporation in schools, and specifically in schools in the United States and Costa Rica, both top migrant destination countries in their regions. As a sole researcher, the comparative nature of my study restricted the amount of time that I was able to spend in each fieldsite. Although fieldwork for the Costa Rican ethnographic case studywhich is the focus of this article-unfolded over a concentrated period of four months, the depth of my "ethnographic knowing” (Pink \& Morgan, 2013, p. 354) emerged through layers of data collection and analysis that both preceded and expanded beyond my physical time in the field.

Fieldwork took place during the first semester of the Costa Rican school year, from late February to late June of 2013. Previous to this, in the summer of 2012, I conducted exploratory research in Heredia, speaking with teachers in schools recommended by an informant who was a colleague at my alma mater, Universidad Nacional (UNA). I also spoke with officials in the Costa Rican Ministry of Education (MEP) and started review and analysis of documents, such as books, textbooks, newspaper articles, and curriculum materials available in print and online (which continued well into and after fieldwork at EMV). After my visit, I identified EMV as an appropriate focal point for the study and established a relationship with the school via email. Another colleague at UNA supported my communication with the school, acting as the first 
physical point of contact with the principal during a one-on-one meeting to confirm official approval of the study.

Whereas I quickly established a trusting relationship with the principal and administrators, once in Costa Rica, the teachers were initially suspicious of my motives as a researcher investigating the topic of immigration. For example, when sharing that I was interested in looking at the processes of migrant incorporation in Costa Rican schools, teachers would often emphasize that even though EMV had a large Nicaraguan population, Nicaraguan students "no son discriminados" [are not discriminated against]. However, as time went by, teachers positioned me as a fellow colleague and towards the end of the study invited me to speak to the school faculty about dilemmas related to the education of immigrant children.

\section{Methods and Participants}

I visited the school at least three days a week. During the school day, I participated in instructional activities, assemblies, recess, lunch, and special events at the school, interacting with teachers, administrators, and students, and taking extensive notes of all naturally occurring discourse and activities. At the end of the data collection process, I had forty-two fieldnotes, logging a total of one hundred and forty-three hours of participant observation.

Twelve children and three teachers participated in this study. I assigned pseudonyms to all participants to protect their identities. Out of the twelve children participants, two children, Fabio and Rubén, identified as Nicaraguan immigrants. Four of the children were Costa Ricanborn children from families in which one or two of their parents were from Nicaragua. The remaining six children identified themselves and their parents as Costa Rican. In this article, I focus primarily on the experiences of the children from Nicaraguan backgrounds. I conducted, 
audio-recorded, and transcribed semi-structured 20-minute interviews with the twelve student participants as well as three focus groups with four students each.

Three of the teachers at EMV became key participants during my time there: (1) Profe [short for professor, which is used in lieu of teacher] Pamela, the homeroom teacher for 4-A, who also taught Spanish Language Arts and Social Studies; (2) profe Hania, the science and math teacher; and (3) profe Luciana, a member of the schools' committee of inclusión e interculturalidad [inclusion and interculturality]. In addition to our everyday conversations and interactions, which I documented in fieldnotes, I conducted, audio-recorded, and transcribed a semi-structured 40-minute interview with each of the teachers. All interviews and interactions with teachers and students were conducted in Spanish. Translations for all participants and Spanish texts quoted in this article are my own.

I spent the most time at school interacting with Pamela, who had taught for many years in both private and public-school settings, mostly in rural areas, and had just transferred to EMV. Pamela was originally from the province of Guanacaste, in the Costa Rican northwest. Importantly, Guanacaste was originally known simply as Nicoya, an independent political unit, which shortly after the independence of Central American countries (in 1921), annexed to Costa Rica after a cabildo abierto [voter referendum]. Since then, Costa Ricans from the other six provinces have typically referred to people in Guanacaste as "Nicas regalados" [unwanted or uninvited Nicaraguans] and considered them "second-class citizens" while claiming autochthonous Guanacastecan traditions, symbols, and foods as Costa Rican.

\section{Ecologies of Exclusion}

This study took place in the context of a multicultural turn in Latin America (Author, 2013, 2016; Wieviorka, 2014). In Costa Rica, specifically, this manifested in a nation-wide 
education reform to bring more awareness to diversity in educational settings. Reform efforts included initiatives such as Entreculturas, which blended discourses of neoliberalism, multiculturalism, and interculturalidad (Author, 2014), seemingly decentering colonial notions of citizenship associated with Costa Ricanness (Author, 2017). Yet, even when this discursive blend departed from narratives of Costa Rican exceptionality by making immigrants visible, it nevertheless continued to exclude immigrants from dynamics of civic membership, belonging, and participation granted to the Costa Rican citizenry at large (Author, 2017). This was evident in the complex ecologies of exclusion at play at EMV, through which the students experienced discursive, curricular, and social exclusion.

During my first week of fieldwork, the school principal explained that there were many extranjeros [foreigners] in her school. The extensive use of the word extranjero over inmigrante was a semantic choice that echoed larger social narratives about national belonging and positioned students as others rather than as new members of the nation. In following conversations, the fourth-grade teachers seemed to disagree with the principals' assessment about the number of extranjeros, as they systematically denied or played down the presence of immigrant children in their classroom. I wondered at the time why that was the case. Then, I met profe Pamela. Profe Pamela reported having several extranjeros in her class, 4-A. Her class, she explained, was created well into the beginning of the semester because of a "surplus" of students in the other classrooms. Later in the school year, Pamela revealed the criteria that the other teachers used to move students to her class: They had selected the "troublemakers" and "lowachievers," many of whom had repeated grades, who also "happened to be" mostly children from Nicaraguan backgrounds. 
In describing Pamela's class, the computer science teacher said that from all of the fourth-grade classrooms, 4-A was the "más necesitado de amor" [most in need of love], adding "the students in this class have a delicate economic and social situation... It seems to me that the parents of these kids are not interested in their children's well-being." Pamela on the contrary, saw parents as involved and caring, explaining, "[the parents] want [their children] to be better, and they make the effort to send them to EMV." She added, "[they] want something better [for the children]: to take them out of that environment [in La Quebrada]."

Whereas the other fourth grade classrooms surrounded the courtyard at the center of the school, profe Pamela's class occupied a classroom at the margins of this center, in the wing for kindergarten and "special" subjects such as arts, music, and special education. However, because of the late formation of the class, the arts and music teachers already had a full schedule that could not accommodate 4-A. Ironically, although the children in 4-A could not attend arts or music, they constantly heard and saw other students in fourth grade participating in those lessons.

As the semester unfolded, it became evident that the children in 4-A had quite a reputation. The English as a Foreign Language (EFL) and science teachers often described profe Pamela's classroom as "the worst class" and constantly reminded the students of their lowacademic achievement and misbehavior through comparisons with other "better" and "wellbehaved" groups. The children reacted to this positioning in ways that perpetuated it, most of them contributing in one way or another to maintaining the deficit labels that were assigned to them. For instance, they often performed narratives of criminalization by engaging in pranks that involved stealing items and snacks from other children and even the teachers. The science teacher declared once in front of the class that there was no way to make the children behave and 
work orderly, "not even by bringing in the police..." These events reinforced discourses that positioned Nicaraguan immigrants as violent and uninterested in education, without acknowledging the ecologies of exclusion and the deficit narratives in which they were required to operate.

\section{Transnational Lives}

In 4-A, children from Nicaraguan backgrounds reported rich and fluid transnational lives where the labels "Nicaraguan," "Costa Rican," and "extranjero" were rarely used. Instead, they referred to the people in their communities as "friend," "neighbor," "mom," "dad". Their interactions and relationships across both national contexts constituted one singular social field where various transnational interactions and practices took place. They maintained strong connections to their countries of origin and to family members and friends in those countries, often visiting Nicaragua during holidays or summer vacation. They also had frequent interactions with other immigrants in Costa Rica, often neighbors or family members, and in many cases were part of binational households. The extent of their transnational networks was different depending on their particular journeys, with some children also reporting frequent contact with family members in the United States and Panama.

Rubén, who was from Granada in Nicaragua, shared that he and his family immigrated to Costa Rica when he was 4 years old because his grandfather, who lived in Costa Rica with his grandmother, got sick. However, both his grandparents later moved back to Nicaragua and Rubén and his family often visited with them during summer vacation. He also stayed in touch with his grandfather via phone calls. His older sister, who was married, also lived in Nicaragua. 
When I asked Rubén if he identified as Costa Rican or Nicaraguan, he said "both...because there (in Nicaragua) I had friends, family, and siblings too.”

Fabio, also from Granada, had just moved to Costa Rica six months before this study to join his parents, who had already been in the country for six years. Fabio's grandmother and uncles were still in Nicaragua and he stayed in touch with them online. Profe Pamela explained that Fabio's parents had a better financial and legal situation than many of the other immigrant children in the classroom. Apparently, Fabio and his family were legal residents of Costa Rica and could more easily go back and forth between the two countries, a status that not all Nicaraguan families and children have.

Another student, Yolanda, was a child of immigrants who was born in Costa Rica. Her parents met in Nicaragua and moved to Costa Rica about fifteen years ago. Her dad, originally from another Central American country, came to Costa Rica first and then her mother followed. They moved to Costa Rica because "here you make more money," Yolanda shared. Yolanda stayed in touch with her uncles in Nicaragua through frequent phone calls and by visiting, about every three months.

Children like Fabio, Rubén, and Yolanda cultivated their transnational sensitivities in many ways. Rubén, for instance, was fascinated by both Costa Rican and Nicaraguan folkloric tales, whereasFabio was in a Saturday soccer club in his community, where he represented the Costa Rican team in a game in Ecuador. Iván, whose dad was Nicaraguan and mom was Costa Rican, was part of a community group in La Quebrada called Ardillas Recicladoras [Recycling Squirrels] that he attended Wednesdays and Saturdays. When I asked Iván what he liked about being in this group, he said "[I like it because] one helps the world, one helps the world not to be polluted." Ivan's uncle, originally from Nicaragua, was the leader of the group, and Iván's sister, 
cousin, as well as other community members both Nicaraguan and Costa Rica, participated in the project.

The children in Profe Pamela's class were actively engaged in the construction of transnational identities and relationships. On one hand, they did so by staying in touch with relatives, going back to their (or their parents') countries of origin, and maintaining cultural traditions (e.g. cuisine). On the other hand, they were eager participants in activities and communities that nurtured their feelings of belonging and membership to Costa Rica and that provided them with opportunities to make valuable contributions to Costa Rican society.

\section{The Disruption of Transnational Social Fields}

Although the transnational identities and networks of students from Nicaraguan backgrounds were typically nurtured in their families and communities, they were constantly disrupted at school. I found that immigrant children were confronted with a double marginality (Dyrness \& Sepúlveda, 2015) in which they were not only excluded from the Costa Rican imagined community, but also prevented from entering the Nicaraguan national imaginary. This double marginality was constructed and perpetuated during official school spaces through discourses that disrupted Nicaraguan historical narratives, social networks, and linguistic practices, and thus discouraged students from solidifying their existing transnational forms of being and belonging.

\section{Historical Disruption}

Schools have a crucial role in the discursive construction of the nation through the perpetuation of dominant historical narratives. These national narratives, "attempt to bring continuity to the past, present, and future, making the nation a perpetual protagonist. In such narratives, the stories that are told - and how they are told - are as important as those that must 
be forgotten" (Carretero, Lopez, Gonzalez, \& Rodriguez-Moneo, 2013, p. 154). One of the types of disruption that I observed at Montaña Verde involved the exclusion or distortion of Nicaraguans in the Costa Rican retelling of historical events taking place in the Central American region.

An example of this historical disruption is the Costa Rican representation of the defeat of William Walker, an American from Tennessee who in 1856 had intended to turn the countries in Central America into slave states to join the Southern United States. In the Costa Rican narrative, Costa Ricans were the main actors in the defeat of Walker and his filibusteros [filibusters]. This is a narrative that is commonly perpetuated in schools during social studies lessons and actos cívicos [school assemblies]. Actos cívicos in schools in Costa Rica celebrate a series of holidays highlighting national symbols, values, people, and events. Hernández Cruz (2000) calls these assemblies held on patriotic occasions, rituales de la patria [motherland rituals]. These "acts of authority" or "authorized acts" (Bourdieu, 1991, p. 111) functioned as mechanisms that promoted the disruption of students' transnational social fields.

During the school's re-enactment of the Batalla de Santa Rosa [The Battle of Saint Rose] — the only battle against Walker fought on Costa Rican soil—-the assistant principal explained to the children,

The filibusters were supported by a country that was OK with enslaving us. They were a group of cowards because they left running when Costa Ricans, barefoot, defended their country... The villain of this story, William Walker, was a fine and sophisticated loser who wanted to make easy money. Invited by the liberals of Nicaragua, he took advantage, but he did not foresee the Costa Rican army, that according to them was made up of ignorant countrymen... 
In her account, there was no mention of the civil war in Nicaragua that acted as a backdrop to William Walker's intervention. Instead, the Costa Rican narrative presented Nicaraguans as supportive of colonial powers. Neither did this narrative mention the Allied Central American Army and Nicaraguan liberals who fought against Walker in subsequent battles that took place in Nicaragua and that finally defeated him in 1857 . On the contrary, the battle was presented as an isolated event exemplifying the prowess and virtue of Costa Ricans—-stressing the perceived lack of morals of people of the United States and either the gullibility or culpability of Nicaraguansand not as part of a chronology of resistance taking place in both Nicaragua and Costa Rica with consequences for the entire Central American region.

One of the teachers, Profe Luciana, a member of the schools' committee of inclusión e interculturalidad [inclusion and interculturality], spoke about realizing that she had never really thought about how Nicaraguans commemorate the defeat of William Walker, sharing,

The other day we went to see the cantata [a play that commemorates the war of 1856 that was the result of William Walker's invasion, also known as la Campaña Nacional de Costa Rica] in La Quebrada... I went with a teacher from that community who is Nicaraguan, and she told me that in Nicaragua they also celebrate the same, the burning of the mesón but with Nicaraguan heroes. I realized it had never occurred to me to ask, "How is this day celebrated in Nicaragua?" The same with Independence Day: I wonder if Nicaraguan children also know that they are part of this Central American festivity. Luciana was referring to the Segunda Batalla de Rivas [Second Battle of Rivas] that took place on April 11, 1856 in Rivas, Nicaragua, and in which Costa Rica’s national hero, Juan Santamaría, is said to have burned the mesón [inn] occupied by the filibusteros. Nicaraguans also celebrate the Primera Batalla the Rivas [First Battle of Rivas] on June 29, 1855, in which 
Nicaraguan soldiers burned another mesón. Luciana's realization speaks to the role of schools in general and school assemblies in particular in obscuring Nicaraguan perspectives of regional historical events, even for the teachers.

This omission of Nicaragua's role in the events related to William Walker's invasion of Central American countries was also present in the social studies class. Even though the Batalla de Santa Rosa took place and is commemorated on March $20^{\text {th }}$, the event is not formally addressed in the social studies textbook adopted by the school, Saber de Estudios Sociales 4, until the end of the text. As a result, there were no school spaces at the time, other than the acto cívico, for students to unpack those historical events. From my observations, teachers would often skip some of the content of the textbook, particularly if considered a tema transversal [cross-cutting theme], which in many cases included topics related to intercultural issues and holidays.

The pedagogical model at EMV, one that followed a banking education model (Freire, 2008), compounded the omission of timely information about this historical event. A typical social studies lesson in 4-A, as in many Costa Rican schools, consisted of students listening to their teacher lecturing or reading from the social studies textbook, copying questions or text from the board into their notebooks, and working individually or in pairs to write the answers to the questions by quoting directly from the book. Once a student finished her work, she could raise her hand and bring her notebook to profe Pamela at her desk, who would then check her answers.

In this teacher-centered classroom, there were few opportunities for students to interact meaningfully with the content that was presented to them; even in occasions in which the children actively brought up current events that they were interested in, the conversations were short-lived because teachers perceived them to be interruptions to the curriculum. Thus, the 
school-wide actos cívicos, textbooks, and social studies lessons reinforced a Costa Ricancentered representation of historical events, one that assumed a Costa Rica without a Nicaragua and that prevented both Nicaraguan and Costa Rican children from discursively entering into the imagined Nicaraguan community.

\section{Social Disruption}

Levitt and Glick Schiller (2004) differentiate between "ways of being" and "ways of belonging" in social fields. The former refers to the "social relations and practices that individuals engage in rather than to the identities associated with their actions" (p. 1010). The latter refers to "[concrete] practices that signal or enact an identity which demonstrates a conscious connection to a particular group" (p. 1010). The second type of disruption that I observed was the disruption of Nicaraguan students' transnational ways of being and belonging. This type of disruption took place through various processes of socialization that disciplined students to silence, conceal, or deny their Nicaraguan identities and ties during the school day, where they constantly confronted the stigma of being associated with Nicaragua. In fact, during my first visit to the school, Cecilia, the administrative assistant, shared,

[We have] many fullblooded Nicaraguans ... many really violent Nicaraguans...[They are violent] because they are educated there [in Nicaragua], but the ones who are born in Costa Rica, they eventually adapt. [Although] the mothers, who are usually single mothers, they take them back to Nicaragua [to visit]."

Cecilia's portrayal of Nicaraguan children echoed a pervasive (dominant) narrative about Nicaraguans - that they are fundamentally violent — while also discursively positioning Costa 
Ricanness and Costa Rican education as disrupting the transnational formations perceived to be agents in the maintenance of the alleged violence.

The students were well aware of this discourse of Nicaraguan violence. Iván commented that his uncle, aunt, and cousin had left Nicaragua because "people there are always stealing and everything... there is a lot of trash and people are always mugging others." Yet, the children also made comments that contradicted such commonly held assumptions about Nicaraguans. Both Rubén and Fabio told counter-stories that directly complicated or challenged those assumptions while also interrogating the narrative of Costa Rican exceptionality. For example, Rubén was quick to point out, "in Nicaragua there is no theft, and if you steal, you will be beat up." In his comment, Rubén deployed an atypical example of Nicaraguan violence: One that portrayed violence only as a resource to uphold the values of honesty and fairness. Like Rubén, Fabio's memories of life in Nicaragua problematized narratives about the conspicuous violence of Nicaraguans, mentioning that although there was less "maleza" [evil] in Costa Rica, there were other countries in Central and South America (in addition to Nicaragua) like Guatemala, El Salvador, and Colombia that he had heard were also violent.

During one of the focus group discussions, Rubén said that children in his classroom were always saying "bad words," to which Santiago added "like [the word used for] the people from Nicaragua, who are called Nicas." Santiago's association of the word "Nica" with a bad word was not surprising. "Nica," although short for Nicaraguan (in a similar way as Tico is for Costa Rican), is often used contemptuously to refer to people from Nicaraguan backgrounds. In explaining why some people used that word, Iván said "well, because they don’t like the people from Nicaragua.” Rubén agreed with Iván’s assessment stating, “There are people who hate Nicaraguans and some Nicaraguans who hate the Ticos." 
Pamela confirmed that at the beginning of the school year some children addressed Nicaraguan children calling them "nicas" and "conchos" [rowdy] and telling them, "go back to your country." When faced with these behaviors, Pamela recognized the role of the school in diffusing the perpetuation of deficit discourses about Nicaraguans. She shared,

I work in the moment. [I tell the children] Today we are here but we do not know if our family is going to become an immigrant family at some point. Whether we go to Nicaragua, Panama, or any other country... We will then be "the different ones" and we would not like... We should not treat others in ways we would not like to be treated, right? So, almost always, I notice that there are tensions at the beginning of the school year, but I try to stop them and clarify things, and to bring the ship to a good landing. The students themselves also explicitly expressed disagreement with the discriminatory treatment of Nicaraguans. Julieta, shared, "[People say that] they [Nicaraguan immigrants] are not normal like us [Costa Ricans]...Almost everybody laughs at them because they are from Nicaragua... [I think that is] bad... and it is not true.” Iván echoed Julieta’s comments, saying "[discrimination] is bad because we are all human beings, and it does not matter how different each of us is, because we are human beings; we are always equal." The children seemed to be using an egalitarian, human rights rhetoric that is common in Costa Rican curricula, and that often makes invisible - through a form of colorblindness - the systems of oppression that Nicaraguan immigrants must face. Although the children denounced the othering of Nicaraguans in their comments, they also discursively perpetuated dominant discourses that positioned Costa Rican identities as "normal" and Nicaraguan identities as "abnormal."

Branding. One of the ways in which Nicaraguan identities where abnormalized was the practice of branding. Although Nicaraguan immigrant children like Fabio and Rubén often 
explicitly self-identified as Nicaraguan, children of immigrants such as Yolanda and Iván rarely, if ever, disclosed that information to their teachers and peers. That was no accident. In 4-A, children who did so were discursively positioned as others through the use of speech acts. An example that illustrates this discursive exclusion was the student practice of "branding" other children by assigning them nicknames that replaced their given names. The use of nicknames is widespread in Costa Rican culture, and many times nicknames are used as terms of endearment. The nicknames used by the children in 4-A were not used in that way, but instead were more indicative of name-calling, making references to perceived physical characteristics of students.

Although the nicknames themselves did not explicitly reference national, racial, or linguistic features, the way in which they were used singled out Nicaraguan children in ways that were both subtle and obvious. For example, at first, the use of nicknames seemed to be a cultural practice applied to all children in the class. However, with time, it became evident that nicknames virtually replaced a student's given name only when that student had explicitly identified herself as Nicaraguan. This was often the case with newcomers who were not yet aware of the hidden rules and practices of their classroom. For other students, the group-created and assigned nicknames were used interchangeably with their name or used less frequently, if at all. Eduardo, one of the students who identified himself and his parents as Costa Rican and who lead the practice of branding, acknowledged that students used nicknames in different ways, one of them being to identify children who they did not trust.

Whereas some students appropriated this speech act, other students resisted it and even perpetuated it. Armando specifically mentioned that he liked his nickname "cara de papa" [potato face] because "potatoes were delicious," re-interpreting and appropriating the practice. Fabio would actively request to his peers, to no avail, not to call him by his nickname. Yet, in 
some instances, he actively performed dominant ways of belonging by perpetuating branding behavior: Creating and using nicknames for new Nicaraguan students joining the class during the school year. Rubén, on the other hand, described the practice as bullying and shared his advice to Fabio's discomfort when being called "Mr. Bean," saying: "Fabio... he is Nicaraguan, and he comes from Granada, like me, so when he has problems here, I tell him that it is better not to... not to get into fights, that he should tell the teacher..." Yet, branding was such as covert mechanism of exclusion and discrimination that teachers were not aware of it. When confronted with name calling in the classroom, they usually brushed it off as one more kind of misbehaving that the children did, using boletas or recados to let parents know about the behavior, but unaware that it was such an elaborate system.

Passing. Whereas Nicaraguan students who were relatively new to Costa Rica would often self-identify as Nicaraguan, the same was not the case for children of Nicaraguan immigrants. On the contrary, children of immigrants would go to great lengths to conceal their Nicaraguan backgrounds in order to pass as Costa Ricans. Passing is a strategy commonly associated with biracial people who conceal aspects of their racial ancestry in order to "crossover," to have access to opportunities that they would not otherwise be able to secure if they identified as Black. For Hobbs (2014) the scholarly focus on the advantages of passing have obscured what is lost when people have to disguise/reject their identities. I take-up this second interpretation of passing, "what is lost," to argue that passing was another mechanism through which students' transnational ties were disrupted. In the case of children from Nicaraguan backgrounds in Costa Rica, I use the concept of passing in connection to their practice of concealing aspects of their (trans)national identities, primarily their linguistic repertoires. 
In Costa Rica, Nicaraguans have historically used the practice of passing (Alvarenga, 2004), specifically passing as Guanacastecans, as a "process of mutation" (p. 262), a "defensive strategy in the face of ethnic discrimination" (p. 261). One of the people interviewed by Alvarenga (2004) shared, "I tell all people who ask me that question that I'm from Guanacaste, not because I want to deny my homeland, but because you can't just tell anyone that [you're from Nicaragua]" (p. 260). Guanacastecans are typically assumed to be darker than Costa Ricans from the Central Valley_a trait commonly associated with Nicaraguan immigrants_ — and to have a distinct accent that separates them from Costa Ricans in other provinces, one that more closely resembles what is perceived to be a "Nicaraguan accent." In passing as Guanacastecans, Nicaraguans are able to perform Costa Ricannes, and thus claim membership and belonging into the national imaginary, a task that would not otherwise be possible.

Children from Nicaraguan backgrounds in 4-A, as young as 9 years old, actively used passing to avoid the stigma of being associated with Nicaragua, even if they or one of their parents had been born in Costa Rica and regardless of their skin color. For example, Iván, who was light-skinned, was initially hesitant to disclose that his father was Nicaraguan. During the interview, when I asked if he had any friends or relatives in another country, he paused for a second and hesitantly said yes. He then shared that his uncle, aunt, and cousin were from Nicaragua, but did not reveal that his dad was also Nicaraguan until well into our conversation. Interestingly, it seemed that Iván was comfortable expressing the national origin of extended family but felt uneasy about the national origin of his immediate family members. He may have felt that the origin of immediate family members, like fathers or mothers, directly affected his own status. 
Yolanda, a dark-skinned student, who had initially hesitated to disclose her mom's Nicaraguan background to me, also concealed that information from her peers. On one occasion, while Yolanda was telling me about Nicaraguan Spanish, Armando excitedly asked, “Are you from Nicaragua too?" Yolanda looked at him anxiously. Her transnational identity had just been exposed publicly. After pausing, she timidly said "no." Armando then looked at her and, and nodding in acknowledgment of her predicament said, "Oh, your parents are.” Yolanda shyly said, "my mom." Armando smiled kindly, and then changed topics, enacting a promise sotto voce, a silent pact to keep her secret.

Such pacts were common occurrences, performed also by Costa Rican students and teachers. Profe Luciana too brought up the practice of passing. She mentioned that during the Juegos Nacionales [National Games], she had asked one of the children from EMV to represent Nicaragua, "since you are from Nicaragua, why don't you carry the torch during the inauguration of the games?" To which the girl replied, "shhhh profe, don't let anybody hear you, don't say it out loud!" Thus, the dilemma that many children of Nicaraguan immigrants experienced: Passing required the creation of alliances to keep a secret in order to eventually let go of the bond that the secret represented in the first place.

\section{Linguistic Disruption}

The third and last type of disruption was linguistic disruption. For Nicaraguan children, Costa Rican Spanish was a form of linguistic capital (Bourdieu, 1991) directly connected to their potential for passing as Costa Rican. One of the key aspects of passing requires that Nicaraguan immigrants change the way they speak. Alvarenga (2004) explains that even when Nicaraguans are able to "fake" a Central Valley or Guanacastecan accent, the former being harder for them, such imitation is not enough. For Alvarenga, "the more light-skinned Nicaraguans, and those 
who have been in the country for a number of years, are those who can more easily fool Costa Rican nationals into taking them for Vallecentralinos" (p. 262). At EMV, "all linguistic practices [and Nicaraguan linguistic practices in particular] were measured against the legitimate practices, i.e. the practices of those who are dominant" (Bourdieu, 1991, p. 53), in this case Costa Rican Spanish in general and a city accent in particular.

Nicaraguan and Costa Rican varieties of Spanish share many characteristics and are mutually intelligible. They also exist along a continuum that spreads across both countries, rather than being contained within a single nation-state. Yet, in Costa Rica, Nicaraguan Spanish has been constructed as a reflection of Nicaraguan undesirability. This construction takes place through the semiotic process of "iconicity" in which linguistic forms come to represent the distinctive qualities assigned to a group of people (Schieffelin, Woolard, \& Kroskrity, 1998).

The children were well acquainted with and participated in this process of linguicism, "a sort of 'linguistically argued racism'... a process by which an unequal division of power is produced and maintained according to a division between groups on the basis of the [variety of the] language that they speak" (Macedo, Dendrinos \& Gounari, 200, p. 61). They often qualified Nicaraguan Spanish as “weird” and "foreign.” For instance, Tomás pointed out, "well, other children might tell them they are from another country, because of their language... the Nicaraguan language." Nicaraguan children themselves pointed out the challenges of having a Nicaraguan accent. Rubén, for example, told me, "Sometimes they [people from Costa Rica] do not understand my language because I speak like this, like with a twisted tongue." When confronted with linguicism, children reacted in different ways. There was a particular instance that I witnessed and that Fabio explained in the following way: "One of them was mocking how 
we [Nicaraguans] talk, and saying "Nica, go away. So I said that everybody, Nicaraguans and Costa Ricans are equal."

The children not only described the stereotypes associated with Nicaraguan Spanish, but also pointed to specific characteristics that made it different. For example, Iván mentioned that Nicaraguan children were often teased, "because of the way they speak." "How do they speak?" I asked, to what he said, "ea" [expression commonly used at the beginning of sentences], "pué"” [“then," used at the end of sentences], and “ándale jo'i'o" [come on dude], imitating what he perceived to be a Nicaraguan accent. In describing Nicaraguan ways of speaking, Ivan identified some linguistic telltales of Nicaraguan Spanish, namely the pronunciation of the syllable-final /s/ sound as a glottal /h/ sound as in the word "pué" instead of "pués," and the dissapearance of the intervocalic /d/ sounds as in the word "jo'i'o" instead of "jodido." Importantly, even with these pronunciation differences, speakers of both Costa Rican and Nicaraguan varieties of Spanish can understand each other. Yet, as Bourdieu (1991) points out, [t]he competence adequate to produce sentences that are likely to be understood may be quite inadequate to produce sentences that are likely to be listened to, likely to be recognized as acceptable" (p. 55).

In cases where there was an absence of linguistic differentiation, raciolinguistic ideologies (Flores \& Rosa, 2015) operated to marginalize Nicaraguans even if they used dominant linguistic forms. That is, Nicaraguan immigrants were positioned as racially different from Costa Ricans and their linguistic practices framed as deficient "regardless of how closely they follow[ed] supposed rules of appropriateness" (p. 149). For example, when talking about Nicaraguan Spanish, Iván pointed out, “[S]ome people always tease them [Nicaraguans] because they are extranjeros and because they are not from here.” For Iván, speech markers were 
symbolic expressions of foreignness: Nicaraguans were bullied not necessarily because of their accent, but because their accent represents their otherness.

\section{Conclusion}

In the context of Escuela Montaña Verde, students' transnationality was silenced by pervasive ideologies operating in the very educational spaces that are meant to promote equity and inclusion. In room 4-A, children from Nicaraguan backgrounds learned a clear message in school: their Nicaraguan histories, social identities, and linguistic practices - deeply connected to those of Costa Rica - were not welcomed. This case illustrates the reanimation of xenophobic nationalism around the world and the dilemmas experienced by nations when they are confronted with cross-border dynamics that test their democratic structures and rhetoric. It also illuminates the contradictions that arise when robust policies to protect the rights of immigrant children are undermined by nation-centered narratives embedded and perpetuated in schools.

My research indicates that because of a focus on nationalism that informs bounded conceptualizations of nationhood and citizenship, schools are missing opportunities to bridge the civic, social, and linguistic ties shared by peoples across national boundaries. As tools of national formation, public schools are inherently connected to and in service of the maintenance of national borders. Therein lies the predicament of multicultural nations. In the words of Audre Lorde (1984): Will the master use her own tools to dismantle her own house? Even in Costa Rica - a country committed to protecting the rights of immigrant children — civic education is deliberately delivered as part of the social studies class, where historical and political aspects of citizenship normalize it as a primarily legal relationship between a citizen and a nation-state. However, as Glick and Schiller (2004) point out "the nation-state container view of society does 
not capture, adequately or automatically, the complex interconnectedness of contemporary reality" (p. 1006).

In the last two decades, unbounded notions of citizenship in education have emerged that highlight diasporic, transnational, cosmopolitan, and multicultural qualities of modern global and multicultural citizenries (Arshad-Ayaz, 2011; Banks, 2008; Dyrness \& Sepúlveda, 2015). Unbounded citizenship is thus imagined as a form of civic belonging, participation, and community that expands beyond a singular nation-state or ethnic group. An unbounded conceptualization of citizenship involves decentering the nation in educational spaces and denationalizing the curricula. In the Costa Rican case specifically, it means providing spaces for Nicaraguan and Costa Rican children to learn the shared histories, transnational ties, and linguistic continuums that bind the two countries together into a transnational social field.

\section{References}

Author (2013, 2014, 2016, 2017a, 2017b)

Ansaldi, W. (2001), 'La temporalidad mixta de América Latina, una expresión del Multiculturalismo', in H. Silveira (ed.), Identidades comunitarias y democracy, Madrid, España: Editorial Trotta, pp. 167-83.

Alvarenga P. (2004) Passing: Nicaraguans in Costa Rica, In Palmer S., Molina I. (Eds) The Costa Rican reader: History, culture, politics, pp. 257-263. London: Duke University Press.

Araya Madrigal, G., \& Hernández Carballo, S. (2011). La interculturalidad en escuelas costarricenses con población inmigrante [Interculturalidad in Costa Rican schools with immigrant populations]. Actualidades Investigativas en Educación 11 (1), 1-28.

Arias, L. (2014). Costa Rica has the highest percentage of migrant population in Latin America, 
study finds. The Tico Times.

Arshad-Ayaz, A. (2011). Making multicultural education work: A proposal for a transnational multicultural education. Canadian Issues, 71-74.

Banks, J. (2008). Diversity, group identity, and citizenship education in a global age. Educational Researcher, 37, 129-139. doi: 10.3102/0013189X08317501

Bartlett, L. (2012). South-south migration and education: The case of people of Haitian descent born in the Dominican Republic, Compare, 42 (3), 393-414.

Bartlett, L. \& Ghaffar-Kucher, A. (2013). Refugees, Immigrants, and Education in the Global South: Lives in Motion. Routledge Research.

Bourdieu, P. (2003). (7th ed). Language and symbolic power. Cambridge, MA: Harvard Press.

Carretero, M., Lopez, C., Gonzalez, M., \& Rodriguez-Moneo, M. (2013). Students historical narratives and concepts about the nation. In M. Carretero, M. Asensio, \& M. RodriguezMoneo, History Education and the Construction of National Identities (pp. 153170). Charlotte, NC: Information Age Publishing.

Castles, S. (2004). Migration, citizenship, and education. In J. Banks (Ed.), Diversity and citizenship education: Global perspectives (pp. 17-48). San Francisco, CA: Jossey-Bass.

Centro Internacional para el Desarrollo Humano. (2004). Perfiles de comunidades: Por qué se escogen las comunidades de Rincón Grande de Pavas y Guararí. Retrived from http://www.cidh.ac.cr/existimos/perfiles-comunidades.pdf, January 14, 2014.

Chrostowsky, M., \& Long, D. (2013). Transnational educational capital and emergent livelihoods: Cultural strategies among repatriated South Sudanese. In L. Bartlett and A. Ghaffar-Kucher, Refugees, Immigrants, and Education in the Global South: Lives in 
Motion. Routledge Research. (pp. 70-84).

Chrush, J., \& Towodzera, G. (2013). The perilous trek: Zimbabwean migrant children and teachers in South Africa. In L. Bartlett and A. Ghaffar-Kucher, Refugees, Immigrants, and Education in the Global South: Lives in Motion. Routledge Research. (pp. 54-69).

de la Garza, R., \& Orozco, M. (2000). Family ties and ethnic lobbies. In R., de la Garza and H. Pachon (Eds.), Latinos and U.S. foreign policy: Representing the "Homeland". New York, Rowman \& Littlefield Publishers.

Dryden-Peterson, S. (2009). Barriers to accessing education in conflict-affected fragile statescase study: Afghanistan. Retrieved from http://projects.iq.harvard.edu/files/wcfia/ files/2942.pdf

Dyrness, A., \& Sepúlveda, E. (2015). Education and the production of diasporic citizens in El Salvador. Harvard Educational Review, 85(1), 108-131.

Ferris, E., \& Winthrop, R. (2010). Education and displacement: Assessing conditions for refugees and internally displaced persons affected by conflict. Retrieved from http://unesdoc.unesco.org/images/0019/001907/190715e.pdf

Flores, N., \& Rosa, J. (2015). Undoing appropriateness: Raciolinguistic ideologies and language diversity in education. Harvard Educational Review, 85(2), 149-171.

Freire, P. (2008) $\left(30^{\text {th }}\right.$ ed.). Pedagogy of the oppressed. NY: Continuum.

Glick Schiller, N. (2005). Transnational social fields and imperialism. Bringing a theory of power to transnational studies. Anthropological Theory, 5(4), 439-461.

Hobbs, A. (2014). A chosen exile: A history of racial passing. Harvard University Press. Hopenhayn, M. (2002), El reto de las identidades y la multiculturalidad, Pensar Iberoamerica, 
Retrieved from http://www.oei.es/pensariberoamerica/ric00a01.htm

International Organization for Migration (2013). Nicaragua. Facts and figures. Retrieved from http://www.iom.int/cms/en/sites/iom/home/where-we-work/americas/central-and-northamerica-and-th/nicaragua.html (accessed January 27 2015)

Jaffe-Walter, R. (2016). Coercive concern. Nationalism, liberalism and the schooling of Muslim youth. CA: Stanford University Press.

Kivisto, P., \& Faist, T. (2010). Beyond a border: The causes and consequences of contemporary migration. Thousand Oaks, CA: Pine Forge Press.

Koh, S. (2010). National identity and young children: A comparative case study of $4^{\text {th }}$ and 5 th graders in Singapore and the United States. (Doctoral dissertation.). Available from ProQuest Dissertations \& Theses database. (UMI No. 3441678).

Levitt, P., \& Schiller, N. (2004). Conceptualizing simultaneity: A transnational social field perspective on society. International Migration Review, 38(8), 1002-1039.

Locke, S., \& Ovando, C. (2012a). South-South migration: Unwelcome Nicaraguan neighbors in Costa Rica. Encyclopaideia, 33(XVI), 135-158.

Locke, S. \& Ovando, C. (2012b). Nicaraguans and the education glass ceiling in Costa Rica: The stranger in our midst. Power and education, 4(2): 127-138.

Lorde, A. (1984). Sister outsider: Essays and speeches. NY: Crossing Press

Macedo, D., Dendrinos, B., \& Gounari, P. (2003). The hegemony of English. Boulder, CO: Paradigm Publishers.

Mahler, S., \& Ugrina, D. (2006). “Central America: Crossroads of the Americas.” Migration Policy Institute. Retrieved from http://www.migrationpolicy.org/article/central- americacrossroads-americas 
Ministerio de Educación de Costa Rica (2013). La educación, un derecho de todos y todas: Compendio de normas acerca del derecho a la educacion de la población migrante y refugiada. San José: Costa Rica.

Moinian, F. (2009). “I'm just me!” Childhood, 16, 31-48. doi:10.1177/0907568208101689

Orozco, M. (2005). Conceptualizing diasporas: Remarks about the Latino and Caribbean experience. Inter-American Development Bank. Retrieved from https://publications.iadb.org/handle/11319/854?locale-attribute=en

Paniagua-Arguedas, L. (2007). Más allá de las fronteras: Accesibilidad de niños, niñas y adolescentes nicaragüenses a la educación primaria en Costa Rica [Beyond frontiers: Accessibility of Nicaraguan children and teenagers to primary education in Costa Rica]. Anuario de Estudios Centroamericanos, 33-34, 153-181.

Pink, S., \& Morgan, J. (2013). Short-term ethnography: Intense routes to knowing. Symbolic Interaction, 36(3), 351-361.

Purcell-Gates, V. (2008, April). Constructions of difference: Families and children on the margins. Paper presented at the American Educational Research Association Annual Meeting, New York, NY, United States. Cultural Practices of Literacy Website.

Purcell-Gates, V., \& Bustos Rojas, I. (2009). Leading with the heart: A cross-cultural analysis of the Latino culture of educación. Retrieved from http://cpls.educ.ubc.ca/content/pdfs/LeadingWithHeart.pdf

Ríos-Rojas, A. (2014). Managing and disciplining diversity: The politics of conditional belonging in a Catalonian institute. Anthropology \& Education Quarterly. 45(1), 2-21. Rosaldo, R. (1997). Cultural citizenship in Island Southeast Asia. Berkeley, CA: University of California Press. 
Ruiz Guevara, L. (2009). Creencias y desarollo integral: Un estudio de casos de una docente costarricense y tres niños nicaragüenses [Beliefs and well-rounded development: A case study of a Costa Rican teacher and three Nicaraguan children]. Actualidades Investigativas en Educación, 9(3), 1-29.

Sandoval-García, C. (2004). Threatening others: Nicaraguans and the formation of national identities in Costa Rica. Athens, Ohio: Ohio University Press.

Schieffelin, B., Woolard, K., \& Kroskrity, P. (Eds.). (1998). Language ideologies: Practice and theory. New York: Oxford University Press.

Wieviorka, M. (2014), 'The end of multiculturalism?' Retrieved from http://wieviorka.hypotheses.org/321 